\title{
IDENTIFIKASI POTENSI LOKAL PADA TUMBUHAN BIJI PEPAYA (CARICA PAPAYA) SEBAGAI OBAT TRADISIONAL MASYARAKAT DI KECAMATAN BANGGAE TIMUR
}

\author{
Nurhikma Ramadhana \\ Program Studi Pendidikan Biologi - FMIPA Universitas Sulawesi Barat \\ e-mail: ramabiologi@gmail.com
}

\begin{abstract}
Abstrak
Biji pepaya merupakan limbah dari buah pepaya yang dibuang oleh masyarakat karena dianggap tidak penting. Sebenarnya biji pepaya dapat diolah menjadi barang yang lebih bermanfaat.Biji pepaya memiliki kandungan - kandungan yang baik untuk tubuh dan dapat mengobati penyakit gagal ginjal usia dini. Karena cukup banyak limbah biji pepaya saat peneliti mengkonsumsi buah pepaya.Peneliti mulai terobsesi meneliti kandungan biji pepaya.Ternyata kandungan dalam biji pepaya tidak bisa diremehkan. Banyak kandungan biji pepaya antara lain, mengandung zat-zat yaitu: alkaloid, steroid, tanin, dan juga minyak atsiri. Secara mendetail, kandungan biji tersebut berupa beberapa asal lemak tak jenuh dalam jumlah tinggi. Asam tersebut adalah oleat dan asam palmiat. Selain itu, biji pepaya juga diketahui mengandung senyawa kimia golongan fenol, terpenoid juga saponin. Senyawa ini bersifat sitoksik, anti-androgen dan berefek estrogenik. Selanjutnya, biji pepaya juga mengandung karbohidrat dalam jumlah kecil, air, protein, dan juga lemak.Salah satu cara pemanfaatan biji pepaya yaitu dengan mengolahnya menjadi obat. Tujuan dari penelitian ini adalah untuk mendapatkan informasi tentang potensi biji pepaya sebagai obat tradisional bagi masyarakat dalam kaitannya dengan penyakit gagal ginjal karena penyakit ini sangat berbahaya dan menguras uang, karena orang yang menderita gagal ginjal akan mengeluarkan biaya sekitar 5 juta lebih setiap minggunya untuk cuci darah, dan cuci darah ini akan membawa efek samping. Oleh karena itu, untuk mencegah penyakit tersebut peneliti memanfaatkan biji pepaya. Metode yang digunakan dalam penelitian ini adalah metode eksperimen dan analis data, tabulasi data dan pustaka. Metode eksperimen dilakukan dengan cara mengolah biji pepaya menjadi obat yang bermanfaat khususnya di kecamatan Banggae Timur. Hasil dari penelitian menunjukkan bahwa biji pepaya dapat diolah menjadi obat, dan hasil dari uji konsumen dapat diambil kesimpulan bahwa rasa dan aroma biji pepaya seperti kopi.
\end{abstract}

Kata Kunci: Biji pepaya sebagai obat tradisional.

\section{PENDAHULUAN}

Buah pepaya adalah buah yang tidak asing di masyarakat. Sehingga buah pepaya sering disebut buah rakyat, dengan harga yang murah. Buah pepaya terdapat biji yang selalu di buang setiap mengupas buah pepaya. Sehingga biji pepaya akan selalu menjadi limbah yang tidak berguna. Pepaya mengandung nutrisi yang amat berlimpah dan amat baik dikonsumsi anakanak hingga lansia (lanjut usia), untuk menjaga kesehatan tubuh. Selain itu, buah yang diduga berasal dari Kostarika dan Meksiko ini, bisa diperoleh di mana saja dan kapan saja, karena buah ini tidak mengenal musim, sehingga bisa terus tumbuh sepanjang masa. Seluruh bagian pepaya, mulai dari akar sampai dengan ujung daunnya - termasuk bunga dan buahnya, mempunyai nilai medis yang tinggi. Bunga pepaya yang telah dimasak dan dimaniskan dengan gula, bisa digunakan untuk mengobati penyakit kuning dan bronchitis ( Krisna, 2005). 
JURNAL SAINTIFIK VOL. 1 NO. 2, JULI 2015

Kulit batang pohon pepaya, bisa digunakan sebagai obat sakit gigi. Akar dan getah pepaya memiliki khasiat yang luar biasa. Keduanya mengandung zat aktif non-gizi, yaitu karpain, karposit, kautsyuk, dan papayotin, yang bisa berfungsi sebagai antibiotik. Akar pepaya juga bisa dibuat teh untuk menghilangkan parasit-parasit usus, mengobati penyakit kuning dan penyakit ginjal, dan menghentikan perdarahan. Getah pepaya juga bisa digunakan untuk menghilangkan jerawat. Caranya: iris buah pepaya hingga keluar getahnya, kemudian oleskan ke bagian wajah yang berjerawat. Biarkan mengering, kemudian basuhlah dengan air sampai bersih. Maka, dalam waktu yang relatif singkat, kulit wajah yang sebelumnya berjerawat akan mulus kembali. Cukup banyak limbah biji pepaya saat peneliti mengkonsumsi buah pepaya, Sehingga Peneliti ingin mulai meneliti tentang kandungan biji pepaya.Ternyata kandungan dalam biji pepaya tidak bisa diremehkan. Banyak kandungan biji pepaya antara lain, banyak mengandung zat-zat antara lain: alkaloid, steroid, tanin, dan juga minyak atsiri. Secara mendetail, kandungan biji tersebut berupa beberapa asal lemak tak jenuh dalam jumlah tinggi. Asam tersebut adalah oleat dan asam palmiat.Selain itu, biji pepaya juga diketahui mengandung senyawa kimia golongan fenol, terpenoid juga saponin. Senyawa ini bersifat sitoksik, antiandrogen dan berefek estrogenik. Selanjutnya, biji pepaya juga mengandung karbohidrat dalam jumlah kecil, air, protein, dan juga lemak yang bermanfaat bagi tubuh (Andi kuncoro 2004).

Pepaya mengandung serat pektin. Serat yang satu ini, memiliki kemampuan yang sangat hebat, yaitu mampu menghilangkan rasa lapar satu hari penuh. Berdasarkan hasil sebuah penelitian yang dimuat di Journal of The American College of Nutrition, orang yang mengonsumsi buah yang mengandung pektin, memiliki rasa kenyang empat jam lebih lama daripada orang yang juga mengonsumsi buah, tapi “ ' $\mathrm{k}$ mengandung pektin. Pektin ini, terdapat di antara kulit dan daging buah. Oleh karena itu, јіка mengupas buah, tidak boleh terlalu tebal, agar pektin tidak terbuang dengan percuma. Selain itu, serat yang dikandung oleh pepaya, sangat halus. Hal tersebut, menjadikan buah ini sangat cocok dikonsumsi oleh berbagai kalangan usia. Penyakit gagal ginjal adalah penyakit yang berbahaya dan menguras uang, karena orang yang menderita gagal ginjal akan mengeluarkan biaya sekitar 5 juta lebih setiap minggunya untuk cuci darah, dan cuci darah ini akan membawa efek samping. Oleh karena itu, untuk mencegah penyakit tersebut peneliti memanfaatkan biji pepaya. Secara bertahap peneliti mulai merubah biji pepaya menjadi obat. Apalagi dengan kealamian biji pepaya sehingga mengurangi penggunaan bahan kimia, dan secaraotomatis mengurangi pencemaran lingkungan ( Aguskrisno 2005).

\section{METODE PENELITIAN}

2.1 Waktu dan Tempat Penelitian

Penelitian ini dilaksanakan pada bulan Februari 2016 sampai dengan bulan November 2016 di kecamatan banggae timur.Adapun alasan memilih masyarakat di kecamatan ini yaitu masyarakat yang terdapat di lokasi ini sangat bervariasi dan berasal dari latar belakang keluarga yang juga bervariasi, di mana masyarakat ini berada pada lingkungan yang kuang sehat.

2.2 Alat dan bahan

Alat dan bahan yang peneliti gunakan dalam penelitian ini murah dan mudah didapat dan hasilnya cukup memuaskan antara lain:

1. Alat

Pisau

Saringan

Baskom

Lengser/ cetakan

2. Bahan

Buah pepaya yang sudah masak ambil bijinya 
Gula merah

Gula putih

2.3 Metode dan Prosedur Pelaksanaan Penelitian

Metode yang digunakan dalam penelitian ini adalah metode experiment dan pustaka. Langkah-langkah experiment sebagai berikut:

Perlakuan A. Mengolah biji pepaya menjadi permen biji pepaya.

- Menyiapkan alat dan bahan.

- Memisahkan biji pepaya dari buah pepaya.

- Mengolah biji pepaya menjadi permen biji pepaya.

Perlakuakan B. Uji konsumen

- Menyiapkan permen biji pepaya.

- Memberikannya kepada konsumen.

- Mencatat pendapat dari konsumen.

2.4 Cara Kerja

Pembuatan permen biji pepaya.

Cara pembuatan serbuk biji pepaya sebagai berikut:

- Siapakan alat dan bahan.

- Ambil buah pepaya yang sudah masak.

- Potong buah pepaya menjadi beberapa bagian.

- Pisahkan biji pepaya dari daging buahnya.

- Keringkan biji pepaya hingga kering.

- Sangrai biji pepaya yang sudah dikeringkan hingga beraroma khas.

- Tumbuk biji pepaya yang sudah di sangrai hingga halus.

- Saring biji pepaya yang sudah ditumbuk halus.

- Serbuk biji pepaya siap digunakan.

Cara pembuatan Obat biji pepaya sebagai berikut:

- Siapakan alat dan bahan.

- Masukkan sedikit air pada panci.

- Nyalakan kompor.

- Rebus air tersebut hingga mendidih.

- Masukkan gula merah pada panci secukupnya.

- Aduk hingga mengental.

- Tambahkan serbuk biji pepaya kedalam panci secukupnya.

- Aduk hingga merata.

- Matikan kompor.

- Masukkan adonan permen kedalam cetakan.

- Cetak sesuai keinginan.

- Tunggu sampai dingin.

- Keluarkan dari cetakan.

- obat biji pepaya siap dikonsumsi. 


\section{JURNAL SAINTIFIK VOL. 1 NO. 2, JULI 2015}

2.5 Skema Pembuatan

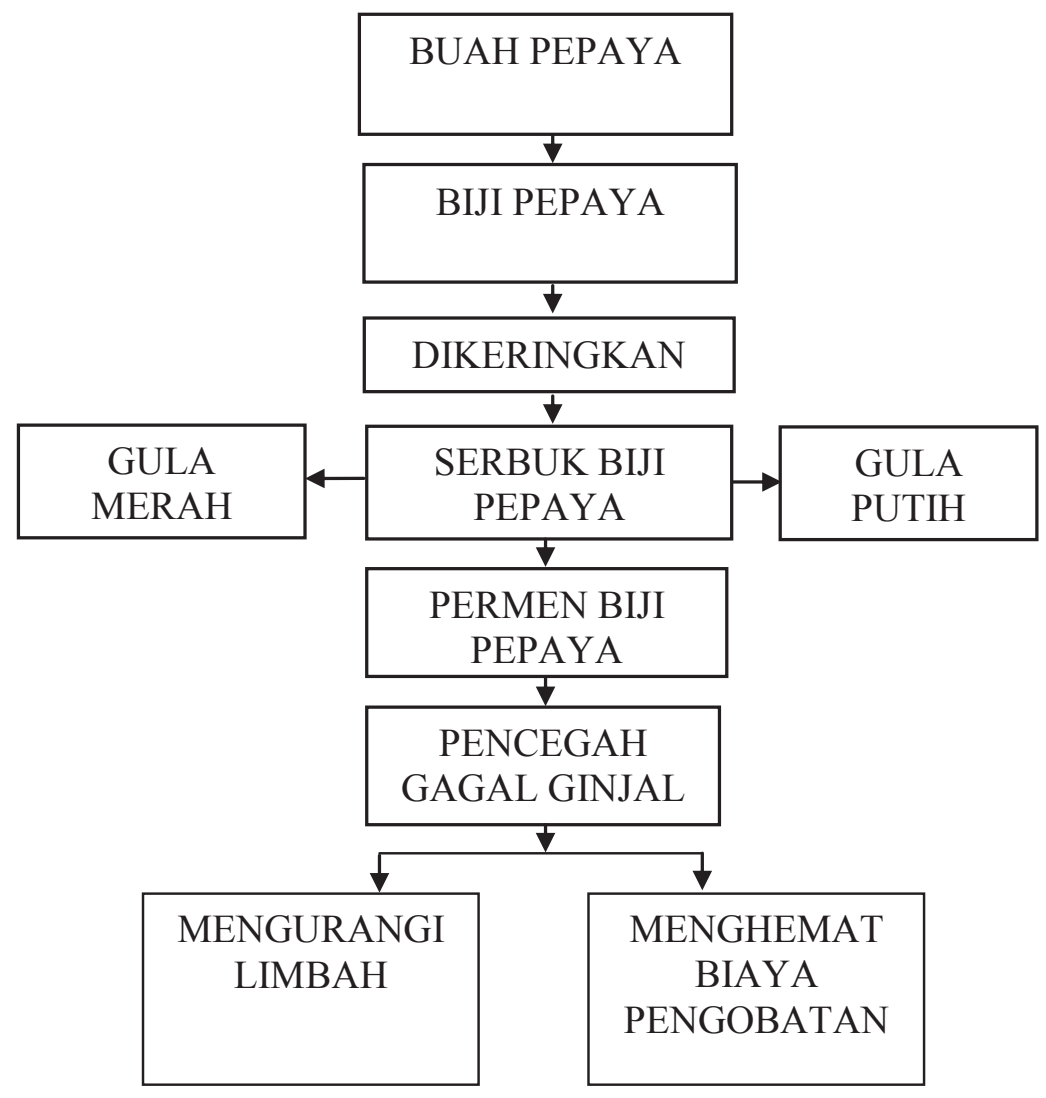

2.6. Bagan diagram alir penelitian

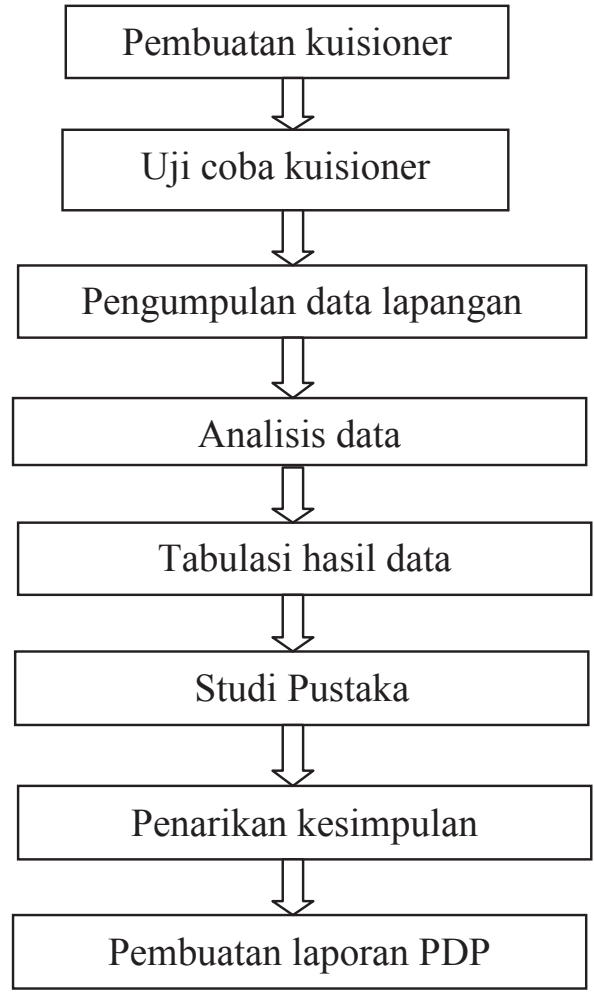


2.7 Penjelasan singkat diagram alir penelitian

a. Pembuatan kuisioner secara serentak pada masyarakat di kecamatan Banggae Timur pada responden yang ingin diteliti.

b. Uji coba kuisioner

c. Pengumpulan data

Teknik pengumpulan data merupakan langkah yang paling penting dalam penelitian karena tujuan utama dari penelitian adalah untuk mendapatkan data.pengumpulan data melalui observasi, wawancara, dan hasil wawancara disini akan memberikan data yang lebih akurat dalam penelitian ini dan juga dokumentasi.

d.

Studi Pustaka kegiatan pemilihan secara teratur dengan cara menggunakan bahan-bahan dokumentasi seperti buku-buku, internet, dll.

e. Analisis Data

Metode analisis data yang digunakan adalah meode analisis data deskriptif

f. Tabulasi Data

Verifikasi data dilakukan dengan mengecek kelengkapan jumlah kuesioner yang terkumpul dan kelengkapan pengisian kuesioner yang telah diisi oleh responden. Tabulasi data adalah proses di mana peneliti merekap semua data yang telah diperoleh.Pengolahan Data secara StatistikData yang akan diperoleh kemudian diolah dengan menggunakan program software SPSS versi 16.0 for windows.

g. Penarikan kesimpulan, Membuat kesimpulan dan rekomendasi untuk berbagai pihak yang terkait.

h. Pembuatan laporan PDP.

\section{HASIL DAN PEMBAHASAN}

Hasil uji konsumen pada 40 orang.Dalam eksperimen ini yang di ujikan adalah rasa obat biji pepaya, dan aroma biji pepaya.Uji konsumen ini dilakukan selama tiga bulan enam hari mulai pada tanggal 15 Februari - November 2016 di peroleh hasil sebagai berikut:

Hasil uji konsumen pada 40 orang adalah sebagai berikut:

Tabel 1. Uji konsumen mengenai rasa obat biji pepaya adalah sebagai berikut:

\begin{tabular}{|l|c|c|c|}
\hline \multirow{2}{*}{ No } & \multicolumn{3}{|c|}{ Uji Konsumen Mengenai Rasa } \\
\cline { 2 - 4 } & Sedikit Pahit & Seperti Kopi & $\begin{array}{c}\text { Pas, tidak terlalu pahit dan } \\
\text { tidak terlalu manis }\end{array}$ \\
\hline 1 & $\checkmark$ & $\checkmark$ & $\checkmark$ \\
\hline 2 & $\checkmark$ & $\checkmark$ & $\checkmark$ \\
\hline 3 & $\checkmark$ & $\checkmark$ & $\checkmark$ \\
\hline 4 & $\checkmark$ & $\checkmark$ & $\checkmark$ \\
\hline 5 & $\checkmark$ & $\checkmark$ & $\checkmark$ \\
\hline 6 & $\checkmark$ & $\checkmark$ & $\checkmark$ \\
\hline 7 & & $\checkmark$ & $\checkmark$ \\
\hline 8 & & $\checkmark$ & $\checkmark$ \\
\hline
\end{tabular}




\section{JURNAL SAINTIFIK VOL. 1 NO. 2, JULI 2015}

\begin{tabular}{|l|c|c|c|}
\hline 9 & $\checkmark$ & $\checkmark$ \\
\hline 10 & & $\checkmark$ & $\checkmark$ \\
\hline 11 & & $\checkmark$ & $\checkmark$ \\
\hline 12 & $\checkmark$ & $\checkmark$ \\
\hline 13 & $\checkmark$ & $\checkmark$ \\
\hline 14 & $\checkmark$ & $\checkmark$ \\
\hline 15 & & $\checkmark$ & $\checkmark$ \\
\hline 16 & & $\checkmark$ & $\checkmark$ \\
\hline 17 & & & $\checkmark$ \\
\hline
\end{tabular}

Tabel 2. Uji konsumen mengenai aroma permen biji pepaya adalah sebagai berikut:

\begin{tabular}{|c|c|c|c|}
\hline \multirow{2}{*}{ No } & \multicolumn{3}{|c|}{ Uji Konsumen Mengenai Aroma } \\
\hline & Sangrai Biji Pepaya & $\checkmark$ & Sedikit Pahit \\
\hline 1 & $\checkmark$ & $\checkmark$ & $\checkmark$ \\
\hline 2 & $\checkmark$ & $\checkmark$ & $\checkmark$ \\
\hline 3 & $\checkmark$ & $\checkmark$ & $\checkmark$ \\
\hline 4 & $\checkmark$ & $\checkmark$ & \\
\hline 5 & $\checkmark$ & $\checkmark$ & \\
\hline 6 & $\checkmark$ & $\checkmark$ & \\
\hline 7 & & $\checkmark$ & \\
\hline 8 & & $\checkmark$ & \\
\hline 9 & & $\checkmark$ & \\
\hline 10 & & $\checkmark$ & \\
\hline 11 & & $\checkmark$ & \\
\hline 12 & & $\checkmark$ & \\
\hline 13 & & $\checkmark$ & \\
\hline 14 & & & \\
\hline 15 & & & \\
\hline 16 & & & \\
\hline
\end{tabular}


JURNAL SAINTIFIK VOL. 1 NO. 2, JULI 2015

\begin{tabular}{|c|c|c|c|}
\hline 17 & & $\checkmark$ & \\
\hline 18 & & $\checkmark$ & \\
\hline 19 & & $\checkmark$ & \\
\hline 20 & & $\checkmark$ & \\
\hline 21 & & $\checkmark$ & \\
\hline 22 & & $\checkmark$ & \\
\hline 23 & & $\checkmark$ & \\
\hline 24 & & $\checkmark$ & \\
\hline 25 & & $\checkmark$ & \\
\hline 26 & & $\checkmark$ & \\
\hline 27 & & $\checkmark$ & \\
\hline 28 & & $\checkmark$ & \\
\hline 29 & & & \\
\hline 30 & & & \\
\hline
\end{tabular}

Pembahasan Uji Konsumen

- Rasa

Pada uji konsumen mengenai rasa obat biji pepaya. Diperoleh hasil bahwa 6 orang menyatakan bahwa rasa obat biji pepaya sedikit pahit, 17 orang menyatakan bahwa rasa obat biji pepaya seperti kopi, 17 orang menyatakan bahwa rasa obat biji pepaya pas. Tidak terlalu pahit dan tidak terlalu manis.

- Aroma

Pada uji konsumen mengenai aroma obat biji pepaya, Diperoleh hasil bahwa 6 orang menyatakan bahwa aroma obat biji pepaya beraroma seperti sangrai biji pepaya. 30 orang menyatakan bahwa aroma obat biji pepaya beraroma seperti kopi, 4 orang menyatakan bahwa aroma obat biji pepaya beraroma sedikit pahit.

\section{KESIMPULAN DAN SARAN}

\section{a. Kesimpulan}

Dari penelitian dan pembahasan diatas dapat diambil kesimpulan sebagai berikut:

1. Biji pepaya dapat dijadikan obat untuk mencegah penyakit gagal ginjal.

2. Rasa dan aroma permen biji pepaya seperti rasaaroma kopi.

b. Saran

Adapun saran yang peneliti sampaikan dalam penelitian ini:

1. biji pepaya yang lebih alami dan dapat dijadikan obat.

2. Agar masyarakat menggunakan biji pepaya untuk pencegahan penyakit gagal ginjal sejak dini.

3. Agar masyarakat menggunakan biji pepaya untuk menghemat pengeluaran pengobatan penyakit gagal ginjal.

4. Dapat mengurangi limbah biji pepaya. 


\section{JURNAL SAINTIFIK VOL. 1 NO. 2, JULI 2015}

\section{DAFTAR PUSTAKA}

Arbianto,Purwo. 2007. Dasar-Dasar Biokimia. Jakarta: Depdikbud.

Aguskrisno. 2005. Mengatasi penyakit gagal ginjal. Surabaya. University Press.

Andi Kuncoro. 2004. Pemanfaatan biji pepaya. Online (http://kun.co.ro/2004/01/11, diakses 20 April 2015.

Amir 2009. Budidaya tanaman. Makassar. Kencana.

Andriani, 2009. Holtikultura Tanaman. Surabaya. University Press.

Buchari. 2010. Biologi Lingkungan. Jakarta. Yudisthira.

Badrianto. 2009. Kandungan biji pepaya. Jakarta. Intan Prawira.

Hertynfrianka. 2010. Analisa Gugus Alkohol. http://hertynfrianka.blogspot.com, diakses tanggal 30 September 2015.

Jarwo 2010. Pemanfaatan tanaman berkhasiat untuk obat. Bandung. Sembari.

Krisna. 2005. Pemanfaatan biji pepaya. Jurusan budidaya pertanian.Bengkulu.

Kartono 2008. Tipe tanaman obat. Semarang. Swaraya.

Nurhikma, R. 2013. Mikrobiologi Terapan. Surabaya: University Press.

Poedjadji,A. 2007. Penyakit gagal ginjal. Jakarta: UI.

Raharjo, 2008.Pencegahan penyakit gagal ginjal.University Press. Surabaya.

Raharjo, 2010.Sistem ekskresi .University Press. Surabaya.

Sabrina 2007. Budidaya Tanaman Pepaya. Surabaya. Grahadi.

Tarsana, 2008. Manfaat mengkonsumsi tanaman papaya. Jakarta. UI. 